\title{
Effects of soil water decline on diurnal and seasonal variations in sap flux density for differently aged Jap- anese cypress (Chamaecyparis obtusa) trees
}

\author{
K. Tsuruta, T. Kume, H. Komatsu, K. Otsuki
}

Tsuruta K., Kume T., Komatsu H., Otsuki K., 2018. Effects of soil water decline on diurnal and seasonal variations in sap flux density for differently aged Japanese cypress (Chamaecyparis obtusa) trees. Ann. For. Res. 61(1): 5-18.

Abstract. The effects of soil drought on transpiration are often neglected when predicting transpiration for forests in humid regions under the influence of the Asian monsoon. These effects have indeed been neglected for Japanese cypress, Chamaecyparis obtusa, a major plantation species in Japan and the surrounding area, probably because previous studies have reported no clear effects of soil drought on transpiration for Japanese cypress forests. However, a few studies have reported an apparent reduction in transpiration with soil drought for young Japanese cypress forests. It remains unclear whether such a reduction in transpiration is limited to young Japanese cypress forests or if it is not uncommon for mature Japanese cypress forests, which occupy a large area in Japan. To clarify this point, we conducted sap flux measurements in a year with soil drought on three differently aged Japanese cypress stands including mature (43 years old) and relatively young (23 and 26 years old) trees. In a diurnal time scale, a cross correlation analysis of sap flux density $\left(F_{\mathrm{d}}\right)$ and vapor pressure deficit (VPD) showed that the time lags between $F_{\mathrm{d}}$ and VPD were 1-3 h in dry soil conditions. These were larger than those of wet soil conditions $(<1 \mathrm{~h})$ for all sample trees. $F_{\mathrm{d}}$ at a given VPD in dry soil conditions was smaller than that in wet soil conditions for all sample trees; a $28 \%-63 \%$ reduction in the rate of change in $F_{\mathrm{d}}$ was observed under dry soil conditions. Because our results were obtained when the non-exceedance probability of recorded monthly precipitation was $9 \%-18 \%$, the results suggest the need to consider the effects of soil drought more extensively. Those effects should be considered for not only relatively young but also mature Japanese cypress when predicting diurnal and seasonal patterns of transpiration in years with soil drought, and when predicting inter-annual patterns of transpiration for Japanese cypress despite humid temperate climate.

Keywords Chamaecyparis obtusa, soil drought, sap flux density, transpiration, water deficit, tree age

Authors. Kenji Tsuruta (ktsuruta@ffpri.affrc.go.jp) - Soil Resources Laboratory, Department of Forest Soils, Forestry and Forest Products Institute, Matsunosato 1, Tsukuba, Ibaraki 305-8687, Japan; Tomonori Kume - School of Forestry and Resource Conservation, National Taiwan University, Taipei 106, Taiwan; 
Hikaru Komatsu - Graduate School of Education, Kyoto University, Kyoto 6068501, Japan; Kyoichi Otsuki - Kasuya Research Forest, Kyushu University, Sasaguri, Fukuoka 811-2415, Japan.

Manuscript received November 27, 2017; revised December 25, 2017; accepted December 28, 2017; online first January 8, 2017.

\section{Introduction}

Transpiration is a major component of water cycling in a forest ecosystem (Jasechko et al. 2013, Schlesinger \& Jasechko 2014), and has strong coupling with carbon cycling as reflected in gross ecosystem production, tree growth, as well as in soil and root respiration (Law et al. 2002, Irvine et al. 2008, Ruehr et al. 2012). Examining transpiration is essential for accurately understanding and predicting water and carbon cycling in a forest ecosystem.

Canopy $\left(G_{c}\right)$ and aerodynamic conductance $\left(G_{\mathrm{a}}\right)$ regulate transpiration (Monteith and Unsworth 1990). $G_{\mathrm{c}}$ is the more important factor controlling transpiration when compared with that of $G_{\mathrm{a}}$ for forests, particularly for those comprised of coniferous species (Jarvis and McNaughton 1986). $G_{c}$ is controlled by environmental factors, such as vapor pressure deficit, solar radiation, and soil moisture (Jarvis 1976). However, the high soil moisture in forests of humid regions has often caused researchers to neglect the effects of soil drought on $G_{\mathrm{c}}$ when predicting transpiration (Ford and Vose 2007, Ewers et al. 2008, Kume et al. 2010). This is indeed the case for Japanese cypress plantation forests, a major forest type in Japan (Japan Forestry Agency 2012). Previous studies modelled $G_{c}$ (or its substitutes, such as transpiration and evapotranspiration) for forests comprised of Japanese cypress (Chamaecyparis obtusa) or other tree species in Japan (Morikawa et al. 1986, Murakami et al. 2000, Tanaka et al. 2002, Watanabe et al. 2004, Kosugi et al. 2006, Kumagai et al. 2008, Komatsu et al. 2006, 2008, 2010, 2014).

Many previous studies have found no clear effects of soil drought on transpiration for 6
Japanese cypress forests (Kosugi et al. 2013, Sun et al. 2014, Tateishi et al. 2015, Tsuruta et al. 2015). However, Hattori et al. (1993) reported a reduction of daily-scale transpiration that was caused by soil drought during the growing season in a 12-year-old Japanese cypress forest with a canopy height of $7.0 \mathrm{~m}$, using a micrometeorological approach. This phenomenon might be specific to young Japanese cypress forests because young or short trees have shallow root systems and therefore are easily affected by soil drought (Irvine et al. 2002, 2004; Kume et al. 2007). If this is the case, the models that ignore the effects of soil drought on transpiration should be useful for predicting transpiration in most cases in humid regions of Asia. It should be kept in mind that young Japanese cypress forests occupy only a limited portion of the total area of Japanese cypress forests in Japan (Japan Forestry Agency 2012). Also, at a diurnal time scale, the commencement and cessation of sap flux lag behind those of transpiration, and the time lag could be prolonged under soil drought conditions because of the effects of hydraulic resistance and capacitance (Phillips et al. 1997). The time lag between the occurrence of sap flux and transpiration might cause errors in transpiration estimates at a diurnal time scale (Phillips et al. 1999, 2004; Kumagai et al. 2009) and has implications related to modelling the soil-plant-atmosphere continuum.

Past attempts have been made to examine the effects of soil drought on transpiration for mature Japanese cypress forests but they have had some shortcomings. Many previous studies used the micrometeorological method that requires a scaffold tower (Hattori et al. 1993, Tanaka et al. 1996, Kosugi \& Katsuyama 
2007, Kosugi et al. 2007, 2013); however, this method is not easily applicable to mature forests with tall trees. Our objective was to examine whether the effects of soil drought on transpiration could be detected in mature and relatively young Japanese cypress forests. We measured transpiration recorded using the sap flux method before and during soil drought, a method that is easily applicable to both young, short and mature, tall forests.

\section{Materials and methods}

\section{Study site}

This study was conducted at the Geisha site of the Kasuya Research Forest, Kyushu Univer-

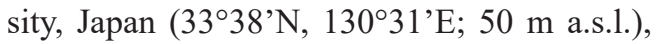
located $\sim 15 \mathrm{~km}$ east of Fukuoka City. Annual mean precipitation and air temperature observed from 2000-2004 were $1,560 \mathrm{~mm}$ and $16.2^{\circ} \mathrm{C}$, respectively.

We conducted measurements in three adjacent Japanese cypress stands with different stand ages and tree sizes; stands were named small (S), medium (M), and large (L) in increasing order of stand age and tree size (Table 1). The shallow soil was less than $34 \mathrm{~cm}$ deep (Fig. S1).

Three sample trees were randomly selected from each stand (Table 1); all stands had sparse understories. The study period, from 22 August, 2006, to 17 November, 2006, experienced less precipitation in the late season (9 October to 17 November) when compared with the early season (22 August to 8 October).

\section{Observations}

\section{Environmental factors}

Solar radiation, air temperature, relative humidity, and precipitation were measured at an open field located approximately $1 \mathrm{~km}$ northwest of the Geisha site. Solar radiation was measured using a LI-200 pyranometer sensor (Li-Cor., Lincoln, NE, USA), and the air temperature and relative humidity were measured using a temperature/humidity probe (DTR503A, Vaisala, Helsinki, Finland). Data were scanned every $10 \mathrm{~s}$ and stored at 10 -min intervals in a data logger (C10X, Campbell Scientific Inc., Logan, UT, USA). Precipitation was measured using a tipping bucket rain gauge (TK-1, Takeda Keiki Co., Tokyo, Japan). These data were also integrated every $10 \mathrm{~min}$ and then stored in the data logger (CR10X). Volumetric soil water content was measured near the sample trees at one point in each stand at a depth of $0-10 \mathrm{~cm}$. The measurements were conducted using a dielectric aquameter sensor (EC-10, Decagon Devices, Inc., Pullman, WA, USA).

\section{Sap flux measurement}

Sap flux density was measured by the thermal dissipation method with Granier-type sensors (Granier 1987). Each sensor consisted of a pair of 20-mm-long probes, $2 \mathrm{~mm}$ in diameter. The probes were inserted into the sapwood approximately $150 \mathrm{~mm}$ apart, vertically. The upper probe, which includes a heater, was supplied with a constant $0.2 \mathrm{~W}$ of power. The heat was dissipated into the sapwood and vertical sap flux surrounding the probe. The temperature difference between the upper and lower probes was measured every $30 \mathrm{~s}$ and averaged every $30 \mathrm{~min}$ by a CR1000 data logger with an AM16/32 multiplexer (both from Campbell Scientific Inc.). The recorded temperature difference was converted to sap flux density $\left(F_{\mathrm{d}}\right)$ according to Granier (1987).

After the sap flux measurements, we used a dye injection method to determine the hydro-active sapwood region in the xylem (Umebayashi et al. 2007, 2008; Tsuruta et al. 2010). Sapwood depth was determined by the stained region of the sample discs. Tsuruta et al. (2010) provides a more detailed description of the dye injection method. For all sample trees, sapwood thickness as determined by this 
was approximately $2.0 \mathrm{~cm}$ (Table 1 ), which is the same length as the sap flow probe. Based on Granier's assumption that the Granier-type sensor integrated one section of the probe intercepting active $F_{\mathrm{d}}$ and the other section in contact with non-conducting xylem, we did not employ the correction proposed by Clearwater et al. (1999).

To consider temporal changes in circumferential variations of $F_{\mathrm{d}}$ within the xylem trunk, we measured $F_{\mathrm{d}}$ at two directions (north and south) within the xylem trunk. Previous studies reported that the circumferential variation in $F_{\mathrm{d}}$ would vary with different soil moisture conditions (Ueda \& Yoshikawa 1994, Lu et al. 2000). We examined the relationship between circumferential variations in $F_{\mathrm{d}}$ and soil moisture. Relationships between $F_{\mathrm{d}}$ at the north and south sides were significantly different during the early and late seasons for four trees among nine trees (Fig. S2; analysis of covariance, $p$ $<0.1$ ). We used mean $F_{\mathrm{d}}$ data of the north and south sides of the trunk in the following analysis.

\section{Method of analysis}

Prior to analyzing the sap flux data, we characterized the intensity of soil drought in this study. The precipitation amount for the current study period was compared with that of the long-term average. For this, non-exceedance probability of the $i^{\text {th }}$ precipitation event $\left(p_{i}\right)$ in ascending order for $N$ years was calculated as $p_{i}=i /(N+1)$ based on the Weibull plotting position equation (Shiiba et al. 2010). This calculation was made using precipitation data collected from 1936 to $2010(N=76)$ at the Iizuka station of the Japan Meteorological Agency, located about $15 \mathrm{~km}$ east of the Geisha site. We calculated the $p_{i}$ of monthly precipitation of September and October 2006 for 76 years. Monthly precipitation recorded in the Geisha site was strongly correlated to that of the Iizuka station (Shinohara et al. 2008). This suggests that monthly precipitation recorded in the Iizuka station can be substitute for that recorded in the Geisha site.

To examine whether soil drought affects transpiration on a diurnal time scale, we examined the time lag between $F_{\mathrm{d}}$ and the vapor pressure deficit (VPD) at an hourly time scale in both the early and late seasons to compare the differences in the time lags between the early and late seasons. Note that the time lag could be prolonged when soil drought affects transpiration (Phillips et al. 1997). To determine the time lag, a cross-correlation analysis was performed using a 1-h-interval dataset. We assumed the lag to be one that maximized the correlation coefficient (Phillips et al. 1999).

To examine whether the effects of soil

Table 1 Characteristics of the three differently aged stands (named S (small), M (medium), and L (large) stands in increasing order of stand age and tree size) and sample trees

\begin{tabular}{lllrllllll}
\hline Stand & No. & $\begin{array}{l}\text { Stand age } \\
(\text { years })\end{array}$ & $\begin{array}{l}\text { DBH } \\
(\mathrm{cm})\end{array}$ & $\begin{array}{l}\text { Tree } \\
\text { height } \\
(\mathrm{m})\end{array}$ & $\begin{array}{l}\text { Stem } \\
\text { density } \\
\text { trees } \\
\left.\mathrm{ha}^{-1}\right)\end{array}$ & $\begin{array}{l}\text { Sapwood } \\
\text { depth } \\
(\mathrm{cm})\end{array}$ & $\begin{array}{l}\text { Sapwood } \\
\text { area }\left(\mathrm{cm}^{2}\right)\end{array}$ & $\begin{array}{l}\text { Leaf } \\
\text { area } \\
\left(\mathrm{m}^{2}\right)\end{array}$ & $\begin{array}{l}\text { Leaf area } \\
\text { Sapwood } \\
\text { area } \\
\left(\mathrm{m}^{2} \mathrm{~cm}^{-2}\right)\end{array}$ \\
\hline S & S1 & 23 & 12.6 & 9.2 & 2,600 & 1.7 & 57.0 & 24.8 & 0.43 \\
& S2 & & 8.4 & 7.7 & & 2.3 & 43.9 & 12.0 & 0.27 \\
& S3 & & 9.3 & 7.0 & & 2.2 & 49.0 & 7.7 & 0.16 \\
$\mathrm{M}$ & M1 & 26 & 17.2 & 11.5 & 1,000 & 2.2 & 103.6 & 25.1 & 0.24 \\
& M2 & & 18.7 & 11.5 & & 2.0 & 104.8 & 39.7 & 0.38 \\
& M3 & & 19.7 & 11.3 & & 2.6 & 137.2 & 61.5 & 0.45 \\
L & L1 & 43 & 34.0 & 17.3 & n. a. & 3.5 & 330.7 & 96.7 & 0.29 \\
& L2 & & 29.0 & 16.4 & & 2.7 & 219.6 & 85.8 & 0.39 \\
& L3 & 25.5 & 18.1 & & 2.1 & 155.8 & 41.8 & 0.27 \\
\hline
\end{tabular}

Note. ${ }^{1}$ Leaf area was measured by destructive sampling (Tsuruta et al. 2010); DBH - diameter at breast height. 
drought on transpiration were detected on a seasonal time scale, we calculated the reduction rate of $F_{\mathrm{d}}$ as follows (Pataki et al. 2000, Kume et al. 2007):

Reduction $=1-\frac{f_{d r y}(\mathrm{VPD})}{f_{\text {wet }}(\mathrm{VPD})}$

where $f_{\text {dry }}(\mathrm{VPD})$ and $f_{\text {wet }}(\mathrm{VPD})$ are the fitted curves for the relationship between daytime mean $F_{\mathrm{d}}$ and daytime mean VPD in the early and late seasons, respectively.

In $f_{\text {dry }}(\mathrm{VPD})$ and $f_{\text {wet }}(\mathrm{VPD})$, the regulation of transpiration by air temperature $\left(T_{\mathrm{a}}\right)$ and $R_{\mathrm{s}}$ was not considered. Although we noticed that transpiration was affected by $T_{\mathrm{a}}$ as well as VPD and $R_{\mathrm{s}}$ (Jones 2014), a meta-analysis of transpiration data for five Japanese cypress forests (Komatsu et al. 2014) demonstrated that the effects of $T_{\mathrm{a}}$ on transpiration were minimal when $T_{\text {a }}$ exceeds $18.8^{\circ} \mathrm{C}$. This condition was generally satisfied during the study period (see the Results). Furthermore, transpiration for conifer species was mainly driven by VPD rather than $R_{\mathrm{s}}$ (Jarvis and McNaughton 1986), suggesting that VPD is a major driving force for $F_{\mathrm{d}}$ in sample trees.

\section{Results}

\section{Environmental conditions and sap flux den- sity}

Monthly precipitation in both September and October 2006 were smaller than the long-term average during the period from 1936 to 2010 (Figure 1). Monthly precipitation in September 2006 and the long-term average precipitation during September were 96 and $197 \mathrm{~mm}$, respectively. Monthly precipitation of $96 \mathrm{~mm}$ in September was the $14^{\text {th }}$-smallest value $\left(p_{14}\right)$ for the 75 years (1936-2010). The $p_{14}$ in September for the 75 years was $18.2 \%$. Monthly precipitation in October 2006 and the longterm average precipitation during October were 22.5 and $94.8 \mathrm{~mm}$, respectively. Monthly precipitation of $22.5 \mathrm{~mm}$ in October was the $7^{\text {th }}$-smallest value $\left(p_{7}\right)$ for the 75 years. The $p_{7}$ on October for the 75 years was $9.1 \%$.

Precipitation occurred frequently in August and early September 2006 (Figure 2), but rarely occurred from late September onward. Soil water content continued to decline in the three stands after late September except after small precipitation events in late October and early November. The mean soil water contents in stands $\mathrm{S}, \mathrm{M}$, and $\mathrm{L}$ in the early season (22 August to 8 October) were $0.20,0.33$, and 0.33 $\mathrm{m}^{3} \mathrm{~m}^{-3}$, respectively. The mean soil water contents in stands $\mathrm{S}, \mathrm{M}$, and $\mathrm{L}$ in the late season $(9$ October to 17 November) were $0.19,0.24$, and $0.22 \mathrm{~m}^{3} \mathrm{~m}^{-3}$, respectively. In stand $\mathrm{S}$, the mean soil water content in the late season was different from that in the early season only slightly, probably because data for the latter half of the late season were missing due to damage to probes.

VPD and $R_{\mathrm{s}}$ did not show clear seasonality during the study period (Figure 2). Day-to-day variations in daytime mean $F_{\mathrm{d}}$ corresponded to those of daytime mean VPD and $R_{\mathrm{s}}$ for all trees (Figure 2). $F_{\mathrm{d}}$ for stand $\mathrm{S}$ was larger than those for stands $\mathrm{M}$ and L. $F_{\mathrm{d}}$ in the late season was smaller than that in the early season for the three stands.



Figure 1 Seasonal variations in long-term (19362010) average precipitation and that in 2006 

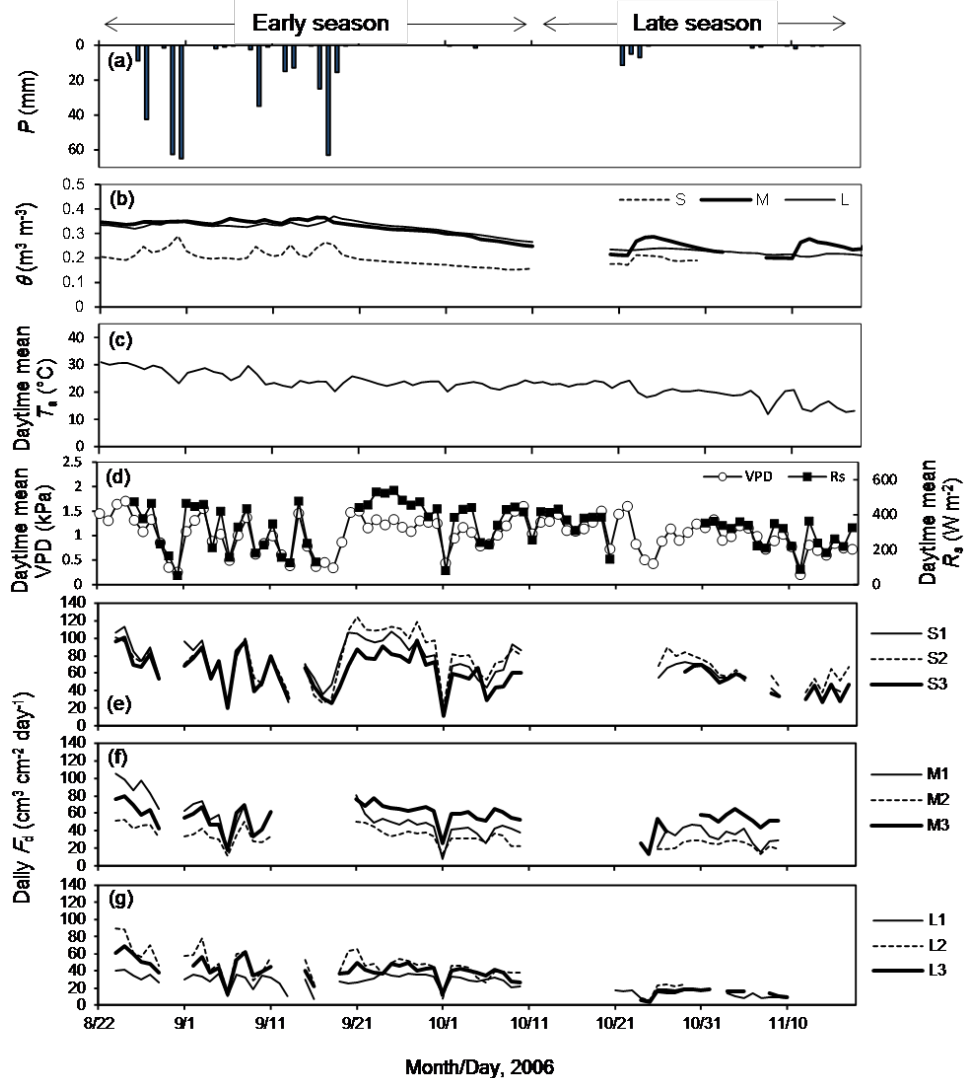

Figure 2 Day-to-day variations in (a) precipitation (P), (b) soil water content at depth of $10 \mathrm{~cm}(\theta)$ for small $(\mathrm{S})$, medium $(\mathrm{M})$, and large (L) stands, (c) daytime mean air temperature $\left(T_{\mathrm{a}}\right),(\mathrm{d})$ daytime mean vapor pressure deficit (VPD) and solar radiation $(R)$, sap flux density $\left(F_{\mathrm{d}}\right)$ for stands (e) S, (f) M, and (g) L for the early and late seasons. A power outage and damage to probes caused some data to be lost.

\section{Effects of soil drought on diurnal variations in sap flux density}

Figure 3 shows diurnal courses of VPD, $R_{\mathrm{s}}$, and $F_{\mathrm{d}}$ of the trees in the three stands on fine days in the early (24 August 2006) and the late (4 November 2006) seasons, in which relatively large VPD, $R$, and $F_{\mathrm{d}}$ were observed. $F_{\mathrm{d}}$ for $\mathrm{S}$ trees was larger than those for $\mathrm{M}$ and $\mathrm{L}$ trees in both seasons. The peak values of $F_{\mathrm{d}}$ were smaller in the late season than in the early season for all three stands. This tendency was generally maintained when we used data 10 for other days. $F_{\mathrm{d}}-\mathrm{VPD}$ relationships within a day were different between the early and late seasons (Figure 4). In the early season, diurnal patterns of $F_{\mathrm{d}}$ showed hysteresis with VPD in a clockwise manner for all three stands; $F_{\mathrm{d}}$ in the morning was larger than that in the evening at a given VPD. Rapid increases in $F_{\mathrm{d}}$ were observed in the morning. Relatively large $F_{\mathrm{d}}$ was maintained in the daytime (13:00-16:00).

However, in the late season, the diurnal patterns of $F_{\mathrm{d}}$ showed hysteresis with VPD in a counter-clockwise manner for all three stands; $F_{\mathrm{d}}$ in the morning was smaller than that in the evening at a given VPD. Rapid increases in $F_{\text {d }}$ were not observed in the morning.

The time lag between $F_{\mathrm{d}}$ and VPD was determined (Table 2) and was generally longer in the late season than in the early season. In the early season, the mean time lag of stands $\mathrm{S}, \mathrm{M}$, and $\mathrm{L}$ was 0 , $0.3 \pm 1.2$, and $0.3 \pm 0.6 \mathrm{~h}$, respectively. In the late season, the mean time lag of stands $\mathrm{S}, \mathrm{M}$, and $\mathrm{L}$ was $0.7 \pm 0.6,1.7 \pm 0.6$, and $1.7 \pm 1.2 \mathrm{~h}$, respectively. The time lag between $F_{\mathrm{d}}$ and $R_{\mathrm{s}}$ was also generally shorter in the early season than in the late season. In the early season, the mean time lag of stands $\mathrm{S}, \mathrm{M}$, and $\mathrm{L}$ was 1.3 $\pm 0.6,2.0 \pm 0$, and $1.7 \pm 0.6 \mathrm{~h}$, respectively. In the late season, the mean time lag of stands $\mathrm{S}$, 
Early season


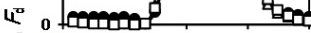


Figure 3 Representative diurnal trends of vapor pressure deficit (VPD, broken line), solar radiation $\left(R_{\mathrm{s}}\right.$, solid line), and sap flux density $\left(F_{\mathrm{d}}\right)$ of small $(\mathrm{S})$, medium $(\mathrm{M})$, and large (L) stands in the (a-d) early and (e-h) late seasons. The figure present data from 24 August 2006 for the early season and 4 November 2006 for the late season.

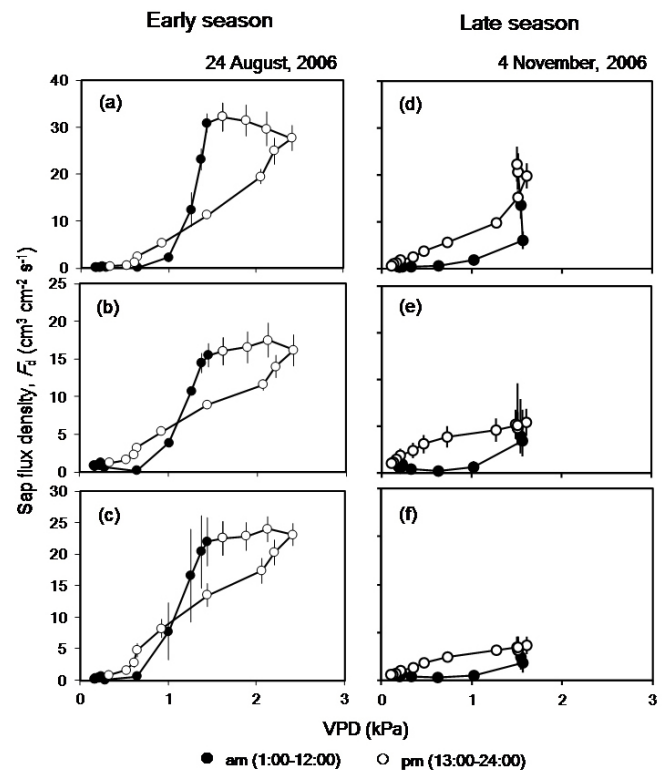

Figure 4 Relationships between sap flux density $\left(F_{\mathrm{d}}\right)$ and vapor pressure deficit (VPD) for sample trees of small (S), medium (M), and large (L) stands in the (a-c) early and (d-f) late seasons. The figure presents data from 24 August 2006 for the early season and 4 November 2006 for the late season. Closed and open circles represent the data for periods from 1:00 to 12:00 and from 13:00 to $24: 00$, respectively. Error bars show the standard error.

Table 2 Summary for cross-correlation analysis between vapor pressure deficit (VPD), solar radiation $\left(R_{\mathrm{s}}\right)$, and sap flux density $\left(F_{\mathrm{d}}\right)$ for wet and dry soil conditions. A time lag $(\Delta T)$ between $F_{d}$ and VPD or $R_{s}$ that was observed to have the highest cross-correlation coefficient $(\mathrm{R})$ in each condition was listed. Data of four days for the $F_{\mathrm{d}}$-VPD pair and three days for the $F_{\mathrm{d}}-R_{\mathrm{s}}$ pair in each season were used for this calculation

\begin{tabular}{|c|c|c|c|c|c|c|c|c|}
\hline \multirow{3}{*}{$\begin{array}{l}\text { Tree } \\
\text { No. }\end{array}$} & \multicolumn{4}{|l|}{ VPD } & \multicolumn{4}{|l|}{$R_{s}$} \\
\hline & \multicolumn{2}{|l|}{ Wet } & \multirow{2}{*}{$\begin{array}{l}\text { Dry } \\
\Delta T(\mathrm{~h})\end{array}$} & \multirow[b]{2}{*}{$R$} & \multicolumn{2}{|l|}{ Wet } & \multicolumn{2}{|l|}{ Dry } \\
\hline & $\Delta T(\mathrm{~h})$ & $R$ & & & $\Delta T(\mathrm{~h})$ & $R$ & $\Delta T(\mathrm{~h})$ & $R$ \\
\hline S1 & 0 & 0.94 & 1 & 0.97 & 1 & 0.97 & 2 & 0.98 \\
\hline S2 & 0 & 0.93 & 1 & 0.95 & 1 & 0.98 & 2 & 0.97 \\
\hline S3 & 0 & 0.94 & 0 & 0.96 & 2 & 0.98 & 2 & 0.97 \\
\hline M1 & -1 & 0.92 & 2 & 0.97 & 2 & 0.96 & 3 & 0.96 \\
\hline M2 & 1 & 0.98 & 2 & 0.97 & 2 & 0.95 & 3 & 0.93 \\
\hline M3 & 1 & 0.98 & 1 & 0.99 & 2 & 0.95 & 2 & 0.94 \\
\hline L1 & 0 & 0.98 & 1 & 0.97 & 1 & 0.94 & 2 & 0.97 \\
\hline L2 & 1 & 0.97 & 3 & 0.67 & 2 & 0.97 & 3 & 0.83 \\
\hline L3 & 0 & 0.97 & 1 & 0.98 & 2 & 0.96 & 3 & 0.96 \\
\hline
\end{tabular}


$\mathrm{M}$, and $\mathrm{L}$ was $2.0 \pm 0,2.7 \pm 0.6$, and $2.7 \pm 0.6$ $h$, respectively.

\section{Effects of soil drought on seasonal variations in sap flux density}

Daytime $F_{\mathrm{d}}$ at a given VPD was lower in the late season than in the early season for all three stands (Figure 5). Slopes of the $F_{\mathrm{d}}$-VPD relationship in the early season were significantly different from those in the late season for S1-3, M4, 5, and L7 ( $p<0.05$; analysis of covariance). Intercepts of the $F_{\mathrm{d}}$-VPD relationship in the early season were significantly different from those in the late season for M6, L7, and L9 ( $p<0.001$; analysis of covariance).

The difference in $F_{\mathrm{d}}$ between the late and early seasons did not seem to be caused by the difference in $T_{\text {a }}$ between the seasons. Indeed, data recorded under different $T_{\mathrm{a}}$ classes were located along the regression line during both the early and late seasons (Figure 6; Figures S3, S4, S5). The data around $18.8^{\circ}$, which is the value of inflection temperature reported by Komatsu et al. (2014), were also located in the regression line. Fig. 6 shows data only for a tree of stand $\mathrm{S}$ as an example. The reduction rates ranged from 0.19 to $0.33,0.05$ to 0.42 , and 0.49 to 0.62 for stands S, M, and L, respectively (Figure 7). The reduction rate was thus larger for stand $\mathrm{L}$ than for stands $\mathrm{S}$ and $\mathrm{M}$ throughout the range of VPD. A significant difference in a reference value of the reduction rate at daytime mean $\mathrm{VPD}=1 \mathrm{kPa}$ between stands $\mathrm{S}$ and $\mathrm{L}$ and be- (a) Stand 5
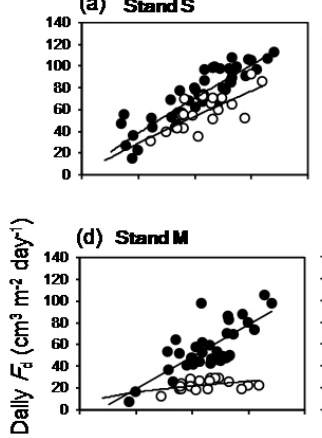

(g) Stand L

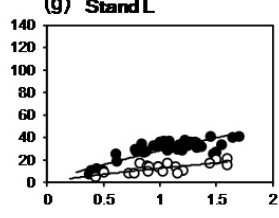

(b)



(e)

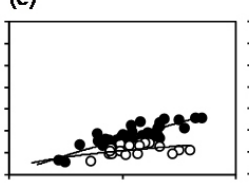

(h)

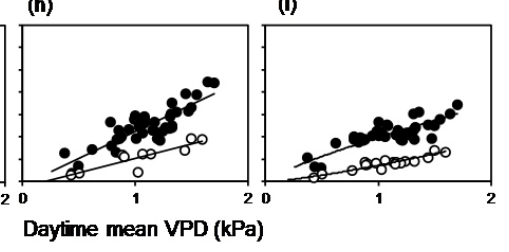

- Early season o Late season

Figure 5 Daily sap flux density $\left(F_{\mathrm{d}}\right)$ in relation to daytime mean vapor pressure deficit (VPD) for small $(\mathrm{S}, \mathrm{a}-\mathrm{c})$, medium $(\mathrm{M}, \mathrm{d}-\mathrm{f})$, and large (L, g-i) stands for the early (closed circles) and late (open circles) seasons.

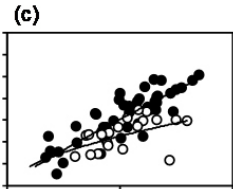

(f)

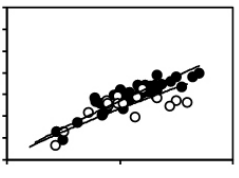




tween stands M and L was observed ( $p<0.05$; one-way analysis of variance).

\section{Discussion and conclusions}

\section{Effects of soil drought on diurnal variations of sap flux density}

Time lags observed in stands $\mathrm{M}$ and $\mathrm{L}$ were slightly larger than those for stand $\mathrm{S}$ in both the early and late seasons (Table 2 ). This could be associated with the differences in sapwood area among the different-sized trees (Table 1). Phillips et al. (1997) and Goldstein et al. (1998) reported that stem water storage capacity causing the time lag between transpiration and stem sap flow depended on the sapwood area which was related to tree size. Larger sapwood area might be a reason for the prolonged time lag observed in stands $\mathrm{M}$ and $\mathrm{L}$.

The time lag between $F_{\mathrm{d}}$ and VPD was longer in the late season than in the early season (Table 2), and a counter-clockwise hysteresis was observed in the late season (Figure 4). These results suggest pronounced tree water recharge occurs during the evening to compensate for tree water discharge imposed by atmospheric demand in the daytime in the late season (Kumagai 2001, Phillips et al. 2003, Čermák et al. 2007, Hentschel et al. 2013).

\section{Differences in the effects of drought on tran- spiration at a seasonal time scale among trees with different sizes and ages}

The reduction rate of $F_{\mathrm{d}}$ ranged from $0.05-$ 0.62 in this study (Figure 7). Previous studies reported that Japanese cypress trees shed their leaves associated with air temperature from October to December (Tadaki \& Kagawa 1968, Utsugi et al. 2001). We could not separate the effects of soil drought (leading to stomatal closure) and leaf fall on reduction of $F_{\mathrm{d}}$ in this study, because soil drought also accelerate leaf fall (e.g., Delzon \& Loustau 2005).
However, Oren et al. (1999) reported that the leaf area reduction by a hurricane did not affect diurnal patterns of $F_{\mathrm{d}}$, while the leaf area reduction affected absolute values of $F_{\mathrm{d}}$ for a Taxodium distichum forest. In this study, diurnal patterns of $F_{\mathrm{d}}$ in the late season were different from those in the early season (Figure 4, Table 2), indicating the detection of the effects of soil drought on $F_{\mathrm{d}}$ in this study.

We observed a pronounced decline of $F_{\mathrm{d}}$ caused by soil drought, when compared with previous studies in Japan. This might have occurred because previous studies were conducted during periods without severe soil droughts. For example, monthly precipitation during observations for the Kiryu Experimental Watershed was approximately the same as that of the long-term average (Kosugi et al. 2013). This suggests that the observation period lacked a period of severe soil drought. One exception reported by Hattori et al. (1993), which observed the effects of soil drought on transpiration in a Japanese cypress forest, reported the critical soil moisture at which transpiration started to decline. Transpiration for the Japanese cypress forest started to decline abruptly when the soil moisture passes the threshold value because of the limitation of extractable soil water. In this study, soil moisture may reach the critical value in the beginning of the late season. Kumagai et al. (2008) reported that soil moisture conditions did not have significant effects on $F_{\mathrm{d}}$ in both upper and lower slopes of a Japanese cedar (Cryptomeria japonica) forest, located about $60 \mathrm{~km}$ south from the present study site, although some dry spells occurred during the same period in that study as in the present study. Japanese cypress trees might have more characteristics that lead to water conservation than Japanese cedar trees under soil drought conditions (Nagakura et al. 2004).

In the present study, stand L had a higher reduction rate of $F_{\mathrm{d}}$ than stands $\mathrm{S}$ and $\mathrm{M}$ under soil drought conditions (Figure 7). This contrasts with our expectation. We expect- 
ed smaller or no reduction in $F_{\mathrm{d}}$ for stand L under soil drought conditions because of the deeper root systems of these relatively large trees (Law et al. 2001; Irvine et al. 2002, 2004; Delzon et al. 2004; Kume et al. 2007). We do not have data related to root depth. However, the shallow soil (Figure S1) should not retain much soil water. The trees in the three stands also should not develop deeper root systems and access deeper soil water. The shallow soil might be one of reasons which all the trees in the three stands suffered from soil drought. One possible reason for the greater reduction in $F_{\mathrm{d}}$ for stand $\mathrm{L}$ might be a relatively large hydraulic resistance between the canopy and roots. A large hydraulic resistance may lead to higher stomatal sensitivity to dry conditions, when compared with relatively young and short trees (Hubbard et al. 1999, Phillips et al. 2002).

Differences in canopy structure and soil water dynamics may also have induced the larger reduction rate in $F_{\mathrm{d}}$ of the $\mathrm{L}$ trees. The $\mathrm{L}$ trees which have larger leaf area compared with the $\mathrm{S}$ and $\mathrm{M}$ trees may have relatively large wet-canopy evaporation. Moreover, wholetree transpiration of $\mathrm{L}$ trees was much larger than those of the $\mathrm{S}$ and $\mathrm{M}$ trees (Tsuruta et al. 2008). Low sensitivity of soil water content to precipitation and the larger decrease of soil water content in Stand L might be caused by larger wet-canopy evaporation and root water uptake for stand L during periods of less precipitation in the late season. We need further investigations for clarifying the effects of tree size on $F_{\mathrm{d}}$.

Our results were based on short-term measurements (about three months) and the number of replicates in this study was only three trees per one stand. However, these would not affect our conclusion that the reduction in transpiration was detected for not only $\mathrm{S}$ but also $\mathrm{M}$ and L stands. First, previous studies reported that seasonal trends in transpiration for temperate evergreen forests in Japan primarily responded to meteorological factors rather than phenology (Komatsu et al. 2006, Kumagai et al. 2008, Komatsu et al. 2014). Note that trees within a stand are under approximately same meteorological conditions. Second, tree-totree variations in the reduction of transpiration with soil drought for each stand were relatively small (Figure 5). Third, tree-to-tree variations in transpiration seasonality are quite small for plantation forests in Japan (Komatsu et al. 2006). Based on these facts, the data of this study generally support our primary conclusion. Measuring physiological characteristics such as leaf water potential would be also useful for clarifying an underlying mechanism for the effect of soil drought on transpiration.

\section{Implications for modelling transpiration}

Although previous studies have examined the effects of soil drought on transpiration for only relatively small and young Japanese cypress trees, we also observed the effects of soil drought on transpiration for mature Japanese cypress trees. Our results were obtained when the non-exceedance probability of recorded monthly precipitation during 75 years was $18.2 \%$ for September 2006, and 9.1\% for October 2006, indicating that monthly precipitation on September and October less than that recorded on September and October 2006 could occur once per 5 and 11 years, respectively. This suggests that the effects of soil drought should be considered not only for young Japanese cypress trees, but also for mature ones when examining transpiration in years with soil drought and inter-annual variations in transpiration. Using transpiration models which neglect a function of soil moisture (Murakami et al. 2000, Tanaka et al. 2002, Watanabe et al. 2004, Kosugi et al. 2006, Ford and Vose 2007, Ewers et al. 2008, Kume et al. 2010, Sawano et al. 2015) for water resource management in Japan and surrounding regions could be problematic from this perspective. Our results suggest the need to include the effects of soil drought on transpiration in those models when 
predicting transpiration from Japanese cypress forests despite humid temperate climate.

\section{Acknowledgments}

The authors are grateful to Mr. Yasuki Shiiba, Mr. Hisami Nagasawa, and Mr. Kiyohiro Kaji (Kyushu University Forest) for their help in felling trees, and Drs. Toshihiro Umebayashi, Ayumi Katayama, Jun'ichiro Ide, and Yoshinori Shinohara for their assistance with our field observations at the study site. Thanks are also due to anonymous reviewers for providing critical comments.

\section{References}

Čermák J., Kučera J., Bauerle W.L., Phillips N., Hinckley T.M., 2007. Tree water storage and its diurnal dynamics related to sap flow and changes in stem volume in oldgrowth Douglas-fir trees. Tree Physiology 27: 181-198. DOI: 10.1093/treephys/27.2.181

Clearwater M.J., Meinzer FC., Andrade J.L., Goldstein G., Holbrook M., 1999. Potential errors in measurements of nonuniform sap flow using heat dissipation probes. Tree Physiology 19: 681-687. DOI: 10.1093/treephys/19.10.681

Delzon S., Sartore M., Burlett R., Dewar R., Loustau D., 2004. Hydraulic responses to tree height growth in maritime pine. Plant Cell and Environment 27: 1077-1087. DOI: $10.1111 /$ j.1365-3040.2004.01213.x

Delzon S., Loustau D., 2005. Age-related decline in stand water use: sap flow and transpiration in a pine forest chronosequence. Agricultural and Forest Meteorology 129:105-119. DOI: 10.1016/j.agrformet.2005.01.002

Ewers B.E., Mackay D.S., Tang J., Bolstad P.V., Samanta S., 2008. Intercomparison of sugar maple (Acer saccharum Marsh.) stand transpiration responses to environmental conditions from the Western Great Lakes Region of the United States. Agricultural and Forest Meteorology 148: 231-246. DOI: 10.1016/j.agrformet.2007.08.003

Ford C.R., Vose J.M., 2007. Tsuga Canadensis (L.) Carr. mortality will impact hydrological processes in southern Appalachian forest ecosystems. Ecological Applications 17: 1156-1167. DOI: 10.1890/06-0027

Goldstein G., Andrade J.L., Meinzer F.C., Holbrook N.M., Cavelier J., Jackson P., Celis A., 1998. Stem water storage and diurnal patterns of water use in tropical forest canopy trees. Plant Cell and Environment 21: 397-406. DOI: 10.1046/j.1365-3040.1998.00273.x
Granier A., 1987. Evaluation of transpiration in a Douglas-fir stand by means of sap flow measurements. Tree Physiology 3: 309-320. DOI: 10.1093/treephys/3.4.309

Hattori S., Tamai K., Abe T., 1993. Effects of soil moisture and vapor pressure deficit on evapotranspiration in a hinoki plantation. Journal of the Japanese Forest Society 75:216-224 [In Japanese with English summary].

Hentschel R., Bittner S., Janott M., Briernath C., Holst J., Pedro Ferrio J., Gessler A., Priesack E., 2013. Simulation of stand transpiration based on a xylem water flow model for individual trees. Agricultural and Forest Meteorology 182-183: 31-42. DOI: 10.1016/j.agrformet.2013.08.002

Hubbard R.M., Bond B.J., Ryan M.G., 1999. Evidence that hydraulic conductance limits photosynthesis in old Pinus ponderosa trees. Tree Physiology 19: 165-172. DOI: $10.1093 /$ treephys/19.3.165

Irvine J., Law B.E., Anthoni P.M., Meinzer F.C., 2002. Water limitations to carbon exchange in old-growth and young ponderosa pine stands. Tree Physiology 22: 189-196 DOI: 10.1093/treephys/22.2-3.189

Irvine J., Law B.E., Kurpius M.R., Anthoni P.M., Moore D., Schwarz P.A., 2004. Age-related changes in ecosystem structure and function and effects on water and carbon exchange in ponderosa pine. Tree Physiology 24: 753-763. DOI: 10.1093/treephys/24.7.753

Irvine J., Law B.E., Martin J.G., Vickers D., 2008. Interannual variation in soil $\mathrm{CO}_{2}$ efflux and the response of root respiration to climate and canopy gas exchange in mature ponderosa pine. Global Change Biology 14: 2848-2859. DOI: 10.1111/j.1365-2486.2008.01682.x

Japan Forestry Agency, 2012. Current state of forest resources. Web: http://www.rinya.maff.go.jp/j/sin_riyou/ kafun/data.html [In Japanese]. Accessed: 11.2017.

Jarvis P.G., 1976. The interpretation of the variations in leaf water potential and stomatal conductance found in canopies in the field. Philosophical Transactions of the Royal Society of London. Series B, Biology Sciences 273: 593-610. DOI: 10.1098/rstb.1976.0035

Jarvis P.G., McNaughton K.G., 1986. Stomatal control of transpiration: scaling up from leaf to region. Advances in Ecological Research 15: 1-49. DOI: 10.1016/S00652504(08)60119-1

Jasechko S., Sharp Z.D., Gibson J.J., Birks J.S., Yi Y., Fawcett P.J., 2013. Terrestrial water fluxes dominated by transpiration. Nature 496: 347-350. DOI: 10.1038/ nature 11983

Jones HG., 2014. Plants and microclimate, Cambridge University Press, Cambridge, 407 p.

Komatsu H., Kang Y., Kume T., Yoshifuji N., Hotta N., 2006. Transpiration from a Cryptomeria japonica plantation, part 2: responses of canopy conductance to meteorological factors. Hydrological Processes 20: 1321-1334. DOI: 10.1002/hyp.6094

Komatsu H., Maita E., Otsuki K., 2008. A model to estimate annual forest evapotranspiration in Japan from mean annual temperature. Journal of Hydrology 348:330-340. DOI: 10.1016/j.jhydrol.2007.10.006 
Komatsu H., Kume T., Otsuki K., 2010. A simple model to estimate monthly evapotranspiration in Japan from monthly temperature. Hydrological Processes 24: 1896-1911. DOI: 10.1002/hyp.7622

Komatsu H., Shinohara Y., Kumagai T., Kume T., Tsuruta K., Xiang Y., Ichihashi R., Tateishi M., Shimizu T., Miyazawa Y., Nogata M., Laplace S., Han T., Chiu C.W., Ogura A., Saito T., Otsuki K., 2014. A model relating transpiration for Japanese cedar and cypress plantations with stand structure. Forest Ecology and Management 334: 301-312. DOI: 10.1016/j.foreco.2014.08.041

Kosugi Y., Takanashi S., Matsuo N., Tanaka K., Tanaka H., 2006. Impact of leaf physiology on gas exchange in a Japanese evergreen broad-leaved forest. Agricultural and Forest Meteorology 139:182-199. DOI: 10.1016/j. agrformet.2006.06.009

Kosugi Y., Takanashi S., Tanaka H., Ohkubo S., Tani M., Yano M., Katayama T., 2007. Evapotranspiration over a Japanese cypress forest. I. eddy covariance fluxes and surface conductance characteristics for 3 years. Journal of Hydrology 337: 269-283. doi: 10.1016/j. jhydrol.2007.01.039

Kosugi Y., Katsuyama M., 2007. Evapotranspiration over a Japanese cypress forest. II. Comparison of the eddy covariance and water budget methods. Journal of Hydrology 334: 305-311. DOI: 10.1016/j.jhydrol.2006.05.025

Kosugi Y., Takanashi S., Ueyama M., Ohkubo S., Tanaka H., Matsumoto K., Yoshifuji N., Ataka M., Sakabe A., 2013. Determination of the gas exchange phenology in an evergreen coniferous forest from 7 years of eddy covariance flux data using an extended big-leaf analysis. Ecological Research 28: 73-385. DOI: 10.1007/ s11284-012-1019-4

Kumagai T., 2001. Modeling water transportation and storage in sapwood - model development and validation. Agricultural and Forest Meteorology 109: 105115. DOI: 10.1016/S0168-1923(01)00261-1

Kumagai T., Tateishi M., Shimizu T., Otsuki K., 2008. Transpiration and canopy conductance at two slope positions in a Japanese cedar forest watershed. Agricultural and Forest Meteorology 148: 1444-1455. DOI: 10.1016/j.agrformet.2008.04.010

Kumagai T., Aoki S., Otsuki K., Utsumi Y., 2009. Impact of stem water storage on diurnal estimated of wholetree transpiration and canopy conductance form sap flow measurements in Japanese cedar and Japanese cypress trees. Hydrological Processes 23: 2335-2344. DOI: 10.1002/hyp.7338

Kume T., Takizawa H., Yoshifuji N., Tanaka K., Tantasirin C., Tanaka N., Suzuki M., 2007. Impact of soil drought on sap flow and water status of evergreen trees in a tropical monsoon forest in northern Thailand. Forest Ecology and Management 238: 220-230. DOI: 10.1016/j. foreco.2006.10.019

Kume T., Tanaka N., Kuraji K., Komatsu H., Yoshifuji N., Saitoh T.M., Suzuki M., Kumagai T., 2010. Ten-year evapotranspiration estimates in a Bornean Tropical forest. Agricultural and Forest Meteorology 151: 11831192. DOI: 10.1016/j.agrformet.2011.04.005

Law B.E., Goldstein A.H., Anthoni P.M., Unsworth M.H., Panek J.A., Bauer M.R., Fracheboud J.M., Hultman N., 2001. Carbon dioxide and water vapor exchange by young and old ponderosa pine ecosystems during a dry summer. Tree Physiology 21: 299-308. DOI: 10.1093/ treephys/21.5.299

Law B.E., Falge E., Gu L., Baldocchi D.D., Bakwin P., Berbigier P., Davis K., Dolman A.J., Falk M., Fuentes J.D., Goldstein A., Granier A., Grelle A., Hollinger D., Janssens IA., Jarvis P., Jensen NO., Katul G., Malhi Y., Matteucci G., Meyers T., Monson R., Munger W., Oechel W., Olson R., Pilegaard K., Paw U K.T., Thorgeirsson H., Valentini R., Verma S., Vesala T., Wilson K., Wofsy S., 2002. Environmental controls over carbon dioxide and water vapor exchange of terrestrial vegetation. Agricultural and Forest Meteorology 113: 97-120. DOI: 10.1016/S0168-1923(02)00104-1

Lu P., Müller W.J., Chacko E.K., 2000. Spatial variations in xylem sap flux density in the trunk of orchard-grown, mature mango trees under changing soil water conditions. Tree Physiology 20: 683-692. DOI: 10.1093/ treephys/20.10.683

Monteith J.L., Unsworth M., 1990. Principles of Environmental Physics, Arnold, London, 422 p.

Morikawa Y., Hattori S., Kiyono Y., 1986. Transpiration of a 31-year-old Chamaecyparis obtusa Endl. stand before and after thinning. Tree Physiology 2: 105-114. DOI: 10.1093/treephys/2.1-2-3.105

Murakami S., Tsuboyama Y., Shimizu T., Fujieda M., Noguchi S., 2000. Variation of evapotranspiration with stand age and climate in a small Japanese forested catchment. Journal of Hydrology 227: 114-127. DOI: 10.1016/S0022-1694(99)00175-4

Nagakura J., Shigenaga H., Akama A., Takahashi M., 2004. Growth and transpiration of Japanese cedar (Cryptomeria japonica) and Hinoki cypress (Chamaecyparis obtusa) seeding in response to soil water content. Tree Physiology 24: 1203-1208. DOI: 10.1093/ treephys/24.11.1203

Ohnuki Y., Terazono R., Ikuzawa H., Hirata I., Kannna K., Utagawa H., 1997. Distribution of colluvia and saprolites and their physical properties in a zero-order basin in Okinawa, southwestern Japan. Geoderma 80: 75-93. DOI: 10.1016/S0016-7061(97)00076-1

Pataki D.E., Oren R., Smith W.K., 2000. Sap flux of co-occurring species in a western subalpine forest during seasonal soil drought. Ecology 81: 2557-2556. DOI: 10.1890/0012-9658(2000)081[2557:SFOCOS]2.0. $\mathrm{CO} ; 2$

Phillips N., Nagchaudhuri A., Oren R., Katul G., 1997. Time constant for water transport in loblolly pine trees estimated from time series of evaporative demand and stem sapflow. Trees 11: 412-419. DOI: 10.1007/ s004680050102

Phillips N., Oren R., Zimmermann R., Wright S.J., 1999. Temporal patterns of water flux in trees and lianas in 
a Panamanian moist forest. Trees 24: 116-123. DOI: $10.1007 / \mathrm{s} 004680050216$

Phillips N., Bond B.J., McDowell N.G., Ryan MG., 2002. Canopy and hydraulic conductance in young, mature and old Douglas-fir trees. Tree Physiology 22: 205-211. DOI: 10.1093/treephys/22.2-3.205

Phillips N., Ryan M.G., Bond B.J., McDowell N.G., Hinckley T.M., Čermák J., 2003. Reliance on stored water increases with tree size in three species in the Pacific Northwest. Tree Physiology 23: 237-245. DOI: 10.1093/treephys/23.4.237

Phillips N.G., Oren R., Licata J., Linder S., 2004. Time series diagnosis of tree hydraulic characteristics. Tree Physiology 24: 879-890. DOI: 10.1093/treephys/24.8.879

Ruehr N.K., Martin J.G., Law B.E., 2012. Effects of water availability on carbon and water exchange in a young ponderosa pine forest: Above- and belowground responses. Agricultural and Forest Meteorology 164: 136-148. DOI: 10.1016/j.agrformet.2012.05.015

Schlesinger W.H., Jasechko S., 2014. Transpiration in the global water cycle. Agricultural and Forest Meteorology 189-190: 115-117. DOI: 10.1016/j.agrformet.2014.01.011

Sawano S., Hotta N., Tanaka N., Tsuboyama Y., Suzuki M., 2015. Development of a simple forest evapotranspiration model using a process-oriented model as a reference to parameterize data from a wide range of environmental conditions. Ecological Modelling 309-310: 93-109. DOI: 10.1016/j.ecolmodel.2015.04.011

Shiiba M., Tachikawa Y., Ichikawa Y., 2010. Hydrology, Morikita, Tokyo, 224 p. [In Japanese].

Shinohara Y., Komatsu H., Otsuki K., 2008. Meteorological characteristics of Ochozu Experimental Watershed, Kyushu University Forest, Fukuoka, Japan. Bulletin of the Kyushu University Forests 89: 39-50 [In Japanese with English summary].

Sun X., Onda Y., Otsuki K., Kato H., Hirata A., Gomi T., 2014. The effects of strip thinning on tree transpiration in a Japanese cypress (Chamaecyparis obtusa Endl.) plantation. Agricultural and Forest Meteorology 197: 123-135. DOI: 10.1016/j.agrformet.2014.06.011

Tadaki Y., Kagawa T., 1968. Studies on the production structure on forest (XIII). Seasonal change of litter-fall in some evergreen stands. Journal of the Japanese Forest Society 50: 7-13 [In Japanese with English summary].

Tanaka K., Tanaka H., Nakamura A., Ohte N., Komashi S., 1996. Conductance at a community level and characteristics of $\mathrm{CO}_{2}$ exchange in a hinoki (Chamaecyparis obtusa) stand. Journal of the Japanese Forest Society 78: 266-272 [In Japanese with English summary].

Tanaka K., Kosugi Y., Nakamura A., 2002. Impact of leaf physiological characteristics on seasonal variation in $\mathrm{CO}_{2}$, latent and sensible heat exchanges over a tree plantation. Agricultural and Forest Meteorology 114: 103-122. DOI: 10.1016/S0168-1923(02)00128-4

Tateishi M., Xiang Y., Saito T., Otsuki K., Kasahara T., 2015. Changes in canopy transpiration of Japanese cy- press and Japanese cedar plantations because of selective thinning. Hydrological Processes 29: 5088-5097. DOI: 10.1002/hyp.10700

Tsuruta K., Kume T., Komatsu H., Higashi N., Kumagai T., Otsuki K., 2008. Relationship between tree height and transpiration for individual Japanese cypress (Chamaecyparis obtusa). Journal of Japan Society of Hydrology and Water Resources 21: 414-422 [In Japanese with English summary]. DOI: doi.org/10.3178/ jjshwr.21.414

Tsuruta K., Kume T., Komatsu H., Higashi N., Umebayashi T., Kumagai T., Otsuki K., 2010. Azimuthal variations of sap flux density within Japanese cypress xylem trunks and their effects on tree transpiration estimates. Journal of Forest Research 15: 398-403. DOI: 10.1007/s10310-010-0202-0

Tsuruta K., Komatsu H., Kume T., Shinohara Y., Otsuki K., 2015. Canopy transpiration in two Japanese cypress forests with contrasting structures. Journal of Forest Research 20: 464-474. DOI: 10.1007/s10310-015-0495-0

Ueda M., Yoshikawa K., 1994. Effects of summer dry-period on sap water movement in a tree trunk of Liquidamber formosana HANCE. Journal of the Japanese Forest Society 76: 249-257 [In Japanese with English summary].

Umebayashi T., Utsumi Y., Koga S., Inoue S., Shiiba Y., Arakawa K., Matsumura J., Oda K., 2007. Optimal conditions for visualizing water-conducting pathways in a living tree by the dye injection method. Tree Physiology 27: 993-999. DOI: 10.1093/treephys/27.7.993

Umebayashi T., Utsumi Y., Koga S., Inoue S., Fujikawa S., Arakawa K., Matsumura J., Oda K., 2008. Conducting pathways in north temperate deciduous broadleaved trees. IAWA Journal 29: 247-263. DOI: 10.1163/22941932-90000184

Utsugi H., Araki M., Kawasaki T., Ishizuka M., 2001. Estimation of seasonal change is leaf area index for a Chamaecyparis obtusa stands. Journal of the Japanese Forest Society 83: 359-362 [In Japanese with English summary].

Watanabe T., Yokozawa M., Emori S., Tanaka K., Sumida A., Hara T., 2004. Developing a multilayered integrated numerical model of surface physics - growing plants interaction (MINoSGI). Global Change Biology 10: 963-982. DOI: 10.1111/j.1529-8817.2003.00768.x

Yoshinaga S., Ohnuki Y., 1995. Estimation of soil physical properties from handy dynamic cone penetration test. Journal of the Japan Society of Erosion Control Engineering 48: 22-28 [In Japanese with English summary].

\section{Supporting Information}

The online version of the article includes Supporting Information:

Fig. S1 Profile of the number of blows required for a pene- 
tration of $10 \mathrm{~cm}\left(N_{\mathrm{c}}\right)$ in small, medium, and large stands

Fig. S2 Relationship between daily sap flux density $\left(F_{\mathrm{d}}\right)$ measured at north and south sides for small, medium, and large stands for the early and late seasons.

Fig. S3 Relationship between daytime mean vapor pressure deficit (VPD) and daily sap flux density $\left(F_{\mathrm{d}}\right)$ for the early and late seasons in the small stand.
Fig. S4 Relationship between daytime mean vapor pressure deficit (VPD) and daily sap flux density $\left(F_{\mathrm{d}}\right)$ for the early and late seasons in the medium stand.

Fig. S5 Relationship between daytime mean vapor pressure deficit (VPD) and daily sap flux density $\left(F_{\mathrm{d}}\right)$ for the early and late seasons in the large stand. 